How to Cite

Sofija, G., \& Ivan, T. (2018). Quality of life in children with disabilities placed in foster families. International Journal of Health

\& Medical Sciences, 1(1), 18-27. https://doi.org/10.31295/ijhms.v1n1.35

\title{
Quality of Life in Children with Disabilities Placed in Foster Families
}

\author{
Georgivska Sofija \\ Faculty of Philosophy, Skopje, Macedonia \\ Corresponding author email: Sofija.arnaudova@fzf.ukim.edu.mk \\ Trajkov Ivan \\ Faculty of Philosophy, Skopje, Macedonia
}

\begin{abstract}
In Macedonia, the biggest provider of social protection is the Republic, then the municipalities, the City of Skopje and municipalities in Skopje within their jurisdictions. The Republic of Macedonia establishes the system of social protection and enables its functioning, by providing conditions and measures for social - protective activities. By promoting the process of deinstitutionalization, the idea of preventing the institutionalization of children with moderate and severe mental disability is imposed, as well as the need to initiate activities to support families, including taking responsibility for improving the quality of life of children while keeping them in a home environment. Carers who agree to care for a child within the family will need to provide love, warmth, and care for his health, education, as well as provide stability and security.

Keywords---care providers, children without parental care, social protection.
\end{abstract}

\section{Introduction}

Placement in foster families is also a form of care applied by the social work centers to help children without parents and parental care. The experts from the Centre for Social Welfare estimate whether the careers (care providers) are eligible to care for a child within the family. Carers who agree to care for a child within the family will need to provide love, warmth, and care for his health, education, as well as provide stability and security.

\section{Research Method}

After the merger of the child and family, experts from the Centre for Social Work regularly monitor the development of the child, and at the same time, they help the foster family. The family is considered one of the oldest social groups. It is the basic unit in which the child realizes the initial knowledge of what surrounds him, of good or bad, beautiful and ugly. Within the family, the child receives the needed love and acquires a sense of security. It develops a sense of familiarity, attention, care, and community which will later evolve into knowledge, skills, attitudes and values of a person, as required of children, especially children with special needs.

\section{Results and Analysis}

For a complete image of the condition of the children placed in foster families, this survey also provides with information about the children as well. Further, in the text, we can see the structure of the children placed in foster families on the territory of the Republic of Macedonia.

ISSN 2632-9433

Received Jan 10, 2018 / Accepted Jun 20, 2018 / Published Jul 05, 2018 
Table 1

Gender of the children with disabilities

\begin{tabular}{lll}
\hline Town/City & Male & Female \\
\hline Kriva Palanka & 5 & 2 \\
Skopje & 9 & 11 \\
Prilep & 12 & 27 \\
Krushevo & 6 & 7 \\
Makedonski Brod & 12 & 12 \\
Veles & 1 & 3 \\
TOTAL & 45 & 62 \\
\end{tabular}

The foster families in the Republic of Macedonia look after children of both genders that suffer from different types of disabilities. At this moment, $42,1 \%$ of the fostered children are boys and $57,9 \%$ are girls.

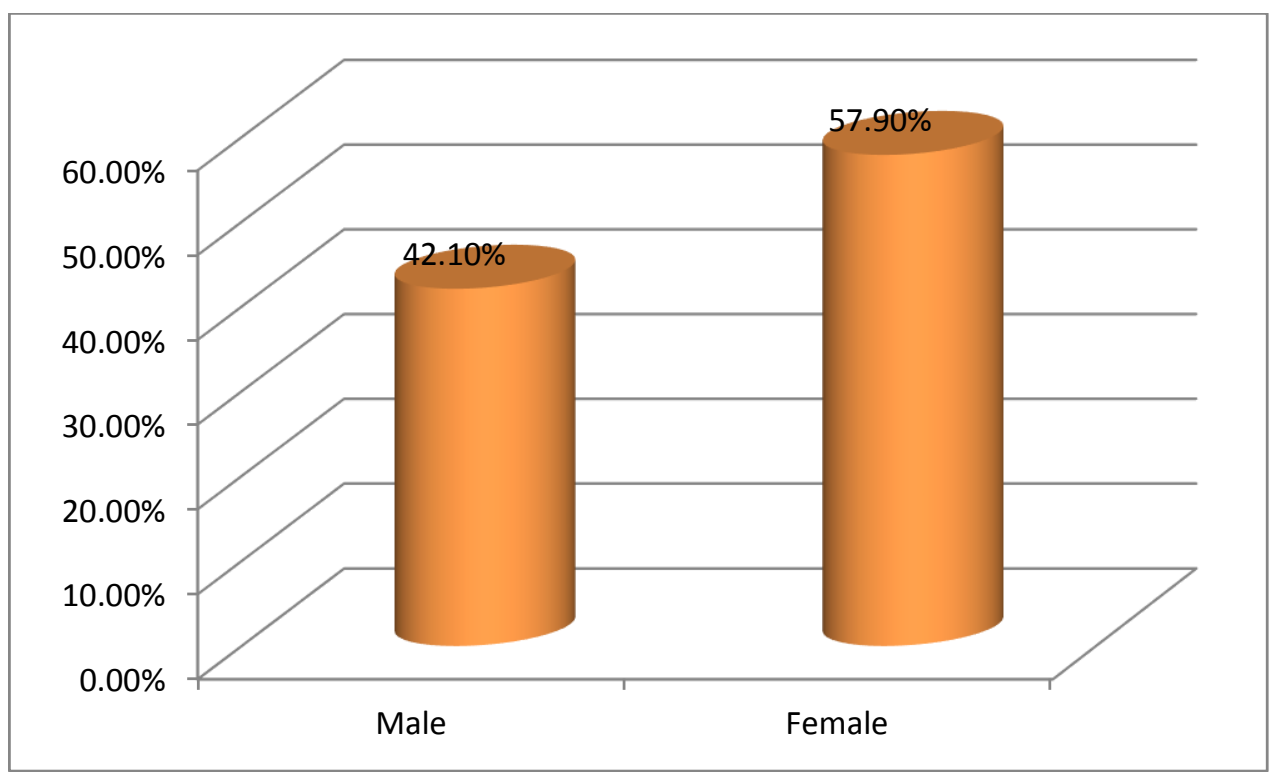

Chart 1. Gender of the children with disabilities

The children in this category are of deferent age. 19,6\% are 6 years and younger, 35,5\% are between the age of 7 to 12 years. $34,6 \%$ of the children are between the age of 13 to 26 years. There is an insignificant percentage of children or $10,3 \%$ who even after turning 26 , stay with their foster families.

Table 2

Age of the children with disabilities

\begin{tabular}{ccccc}
\hline Town/City & Up to 6 years & $7-12$ years & $13-26$ years & Older \\
\hline Kriva Palanka & & & 2 & 5 \\
Skopje & 2 & 6 & 12 & 5 \\
Prilep & 7 & 15 & 12 & \\
Krushevo & 5 & 5 & 3 & 1 \\
Makedonski Brod & 7 & 11 & 4 & 11 \\
Veles & & 1 & 3 & $(10.3 \%)$ \\
Total & 21 & 38 & 37 & $(34.6 \%)$ \\
\hline
\end{tabular}


The difference in ages is given in Chart 2 as well.

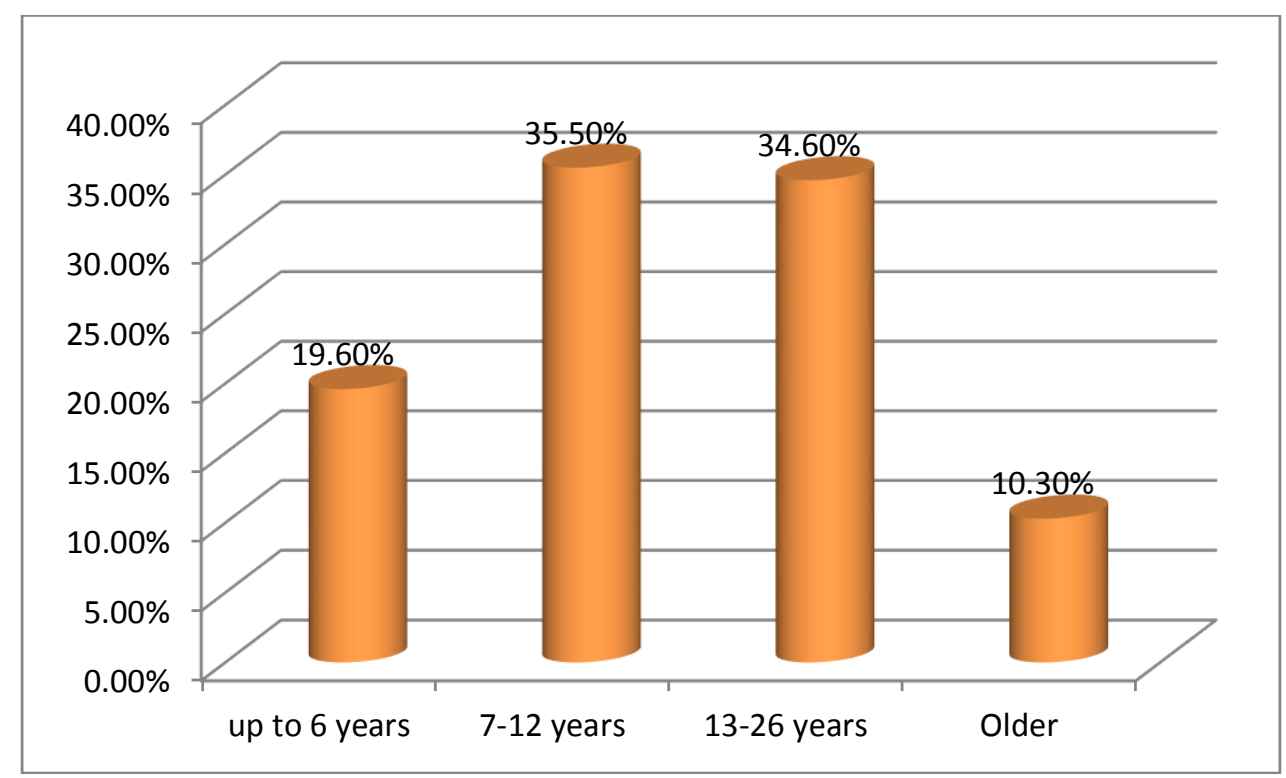

Chart 2. Age of the children with disabilities

Most of the children with disabilities placed in foster families, over $50.0 \%$ of them are children with intellectual disability. The percentage of children with combined disabilities is also very high, where the intellectual disability is also a dominating one. The number of children with vision and hearing impairment is low, whereas the children with motor disabilities whose number is quite high are placed in the combined group.

A detailed and more precise overview of the data can be seen in Table 3 and Chart 3 . Table 33 shows the children with motor disabilities, who have a body impairment of some kind are not even placed in a separate column in the chart. According to the data, there aren't any children with motor disabilities placed in a foster family at the moment. There are cases of children who have heavy intellectual disability combined with heavy motor disabilities. The social workers, who work in this field for many years, point out the fact that there are many children who had heavy disabilities, however, after being placed in a foster family, their condition drastically had changed. This was also confirmed by looking at the children who had heavy motor disabilities, however, after seeing them move freely, without any difficulties and have no visible impairments.

Table 3

Type and level of disability in children

\begin{tabular}{llllllll}
\hline \multirow{2}{*}{ TOWN/CITY } & \multicolumn{5}{c}{ Intellectual disability } & Sight \\
\cline { 2 - 5 } & Light & Moderate & Heavy & $\begin{array}{l}\text { Very } \\
\text { Heavy }\end{array}$ & $\begin{array}{l}\text { Hear } \\
\text { Impairment }\end{array}$ & $\begin{array}{l}\text { Combined } \\
\text { Impairment }\end{array}$ & Disabilities \\
\hline Kriva Palanka & & 3 & & & 1 & & 3 \\
$\begin{array}{l}\text { Skopje } \\
\text { Prilep }\end{array}$ & 3 & 9 & 4 & 11 & & 1 & 4 \\
Krushevo & & 4 & 3 & 3 & & & 7 \\
$\begin{array}{l}\text { Makedonski } \\
\text { Brod }\end{array}$ & & 6 & 7 & & & 1 & 10 \\
Veles & 3 & 1 & & & & & \\
Total & 9 & 26 & 25 & 0 & 1 & 2 & 44 \\
& $(8,4)$ & $(24)$, & $(23)$, & $(0,0)$ & $(0,9)$ & $(1,9)$ & $(41,1)$ \\
\hline
\end{tabular}




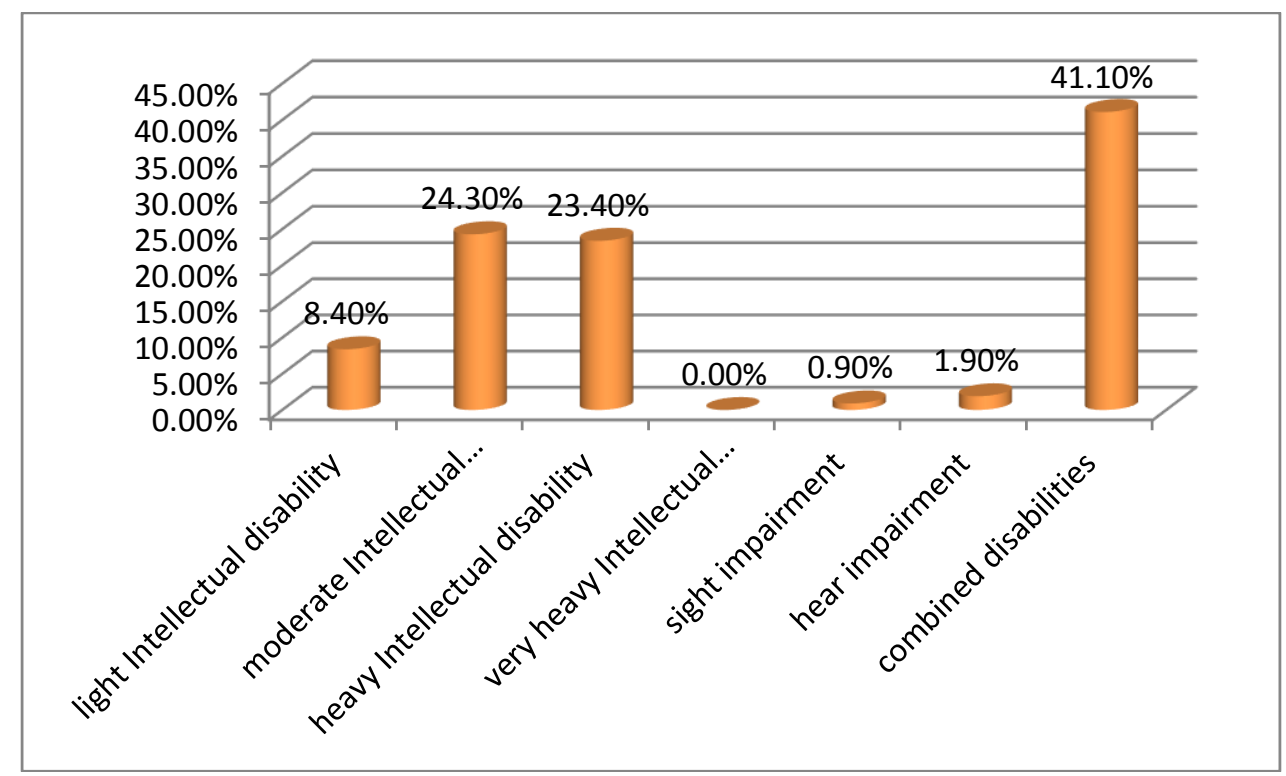

Chart 3. Type and level of disability in children

Table 3 and Chart 3 gives a detailed image of the disabilities in children placed in foster families, according to the type and level of the disability. $8,4 \%$ of the children have a light intellectual disability, $24,3 \%$ have a moderate disability, $23,4 \%$ of them have heavy disabilities, $0,9 \%$ of the children have a vision impairment and $1,9 \%$ of them have a hearing impairment. The largest percentage of children or $41,1 \%$ are children with combined disabilities in their development.

Table 4

Places where the children come from before they were placed in a foster family

\begin{tabular}{llll}
\hline Town/City & Institution & Their biological family & Another foster family \\
\hline Kriva Palanka & 6 & 1 & \\
Skopje & 13 & 3 & 4 \\
Prilep & 33 & 3 & 3 \\
Krushevo & 13 & & \\
Makedonski Brod & 18 & 4 & 2 \\
Veles & & 3 & 1 \\
Total & 83 & 14 & 10 \\
& $(77.6 \%)$ & $(13.1 \%)$ & $(9.3 \%)$ \\
\hline
\end{tabular}




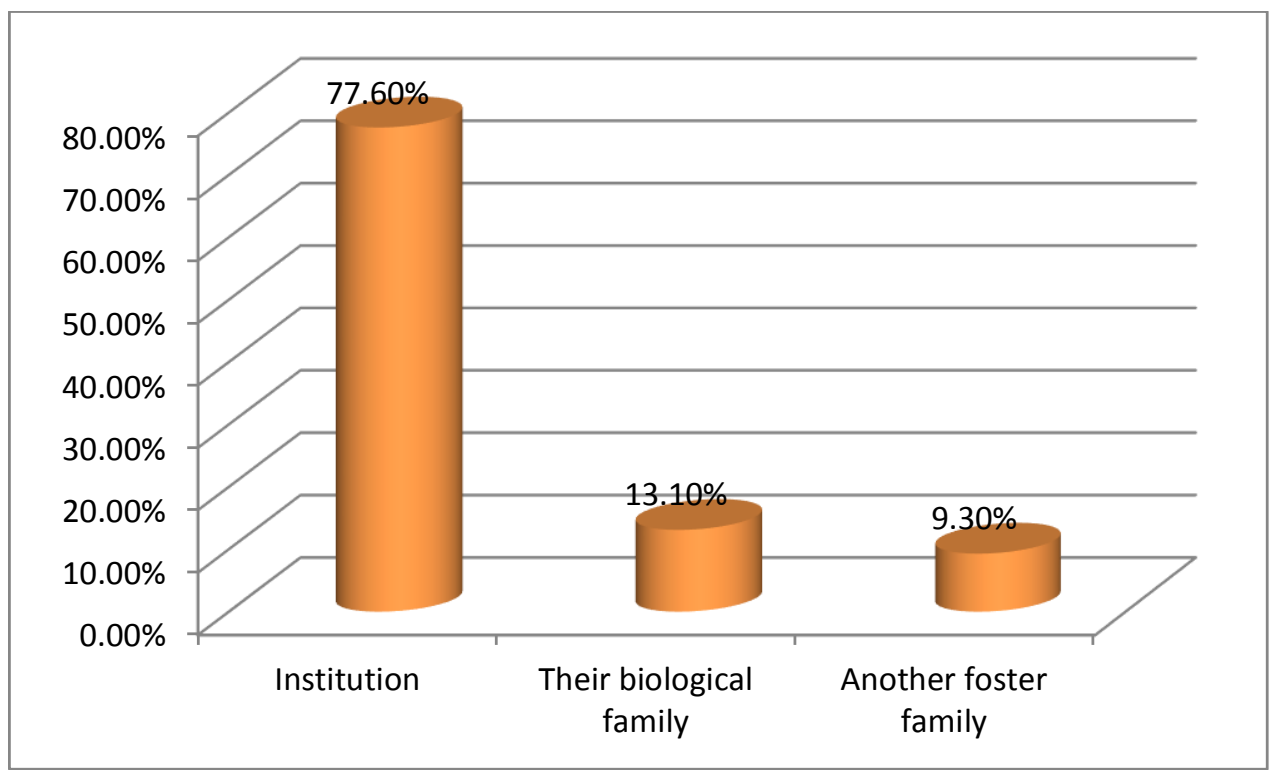

Chart 4. Where do the children come from?

$77,6 \%$ of the children placed in foster families are brought from an institution. These children are usually from The Home for babies and small children in Bitola or the Special Institution in Demir Kapija. In most cases, these children were not provided with professional care and treatments. Such is the case with the children from the Home for babies and small children in Bitola. Most of these children have not spent a long time in an institution before they were placed in a foster family. When they left the institution, they usually had a few months or no more than 3 years, and have felt the family atmosphere, closeness, and attention from early ages. The care providers, as well as the professionals from the social care centers, point out that there is a great improvement in the children after they leave the institution and are placed in a foster family. The improvement is usually in their emotional behaviors, socialization, and in their physique as well. A drastic difference can be seen in the professional opinion and the actual condition of the child. This is especially visible in small children.

The children who have left the Special Institute in Demir Kapija are in a very different situation. Many of them have spent more than 10 years in that institution. Those who were included in the professional treatments through the project "Deinstitutionalization of the children placed in public institutions in the Republic of Macedonia". During their treatment in this project, children learned to develop their positive emotional-social relations, they learned to point out their abilities, look after their health and physical development, as well as accept new experiences with the people, objects and situations in their environment, learn to develop their speech and other forms of communication, learn for form hygienic and other habits etc. Therefore, the children who went to foster families after being part of this project were partially socialized.

$13,1 \%$ of the children placed in foster families have been brought there directly by their biological families. The biological family placed its child with a disability into a foster family usually at a very early age, right after birth or after several months, which is not the case with children without parents or children in educational-social centers. Therefore, children with disabilities feel the warm emotional climate of a family from a very early age.

$9,3 \%$ of the children with disabilities placed in foster families at the moment, were brought there from another foster family. This means that the children, after having left their biological family or institution, have passed a certain period of time in other foster families and failed to remain there for a long time. Through several conversations with the social workers who visited some of the families during this research, the reason for changing foster families is usually the inability of the foster family to adapt to the child with a disability, who has special and specific need for care, as well as cases when the care provider got ill, died etc. 
Table 5

How many years do the children stay with the foster family?

\begin{tabular}{llll}
\hline Town/City & One year & Two to five years & More \\
\hline Kriva Palanka & & & 7 \\
Skopje & 2 & 9 & 9 \\
Prilep & 5 & 6 & 28 \\
Krushevo & 3 & 7 & 3 \\
Makedonski Brod & 4 & 15 & 5 \\
Veles & & 4 & 52 \\
Total & 14 & 41 & $(48.6 \%)$ \\
\hline
\end{tabular}

Most of the children or $48,6 \%$ of them, have spent more than 5 years with their foster families, and they are usually children that have already surpassed their initial problems and are entirely adjusted to the ways the family functions. There is, of course, an adjustment period for all the members of the foster family, to the possibilities, capabilities, and disabilities of the child in need.

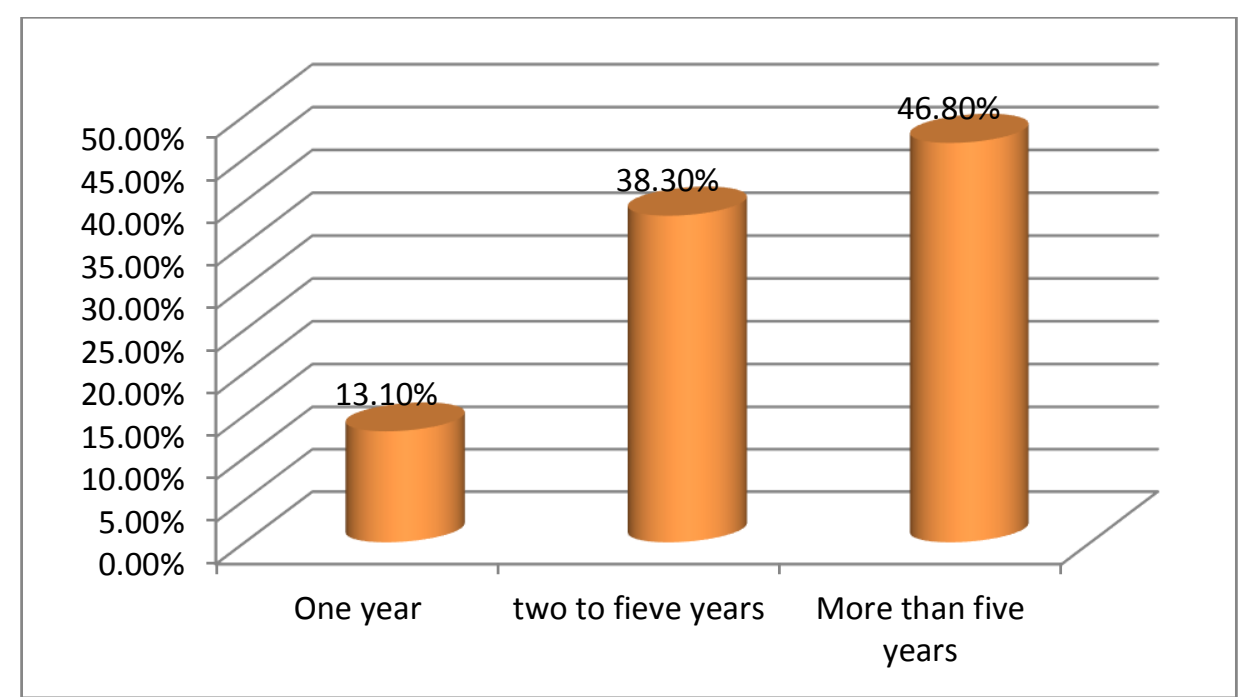

Chart 5. How many years do the children stay with the foster family?

$38,3 \%$ of the children stay with the foster family from 2 to 5 years, while $13,1 \%$ of them stay only for a year with their foster families. The last group of children usually includes children who are very small and they usually get taken to another foster family.

From the social status assessment, one can notice that the social status of the foster families is usually very high. As a confirmation of this data, we asked care providers to provide us with information about whether or not the children play with other children?

Table 6

Does the child play with other children?

\begin{tabular}{llll}
\hline Town/City & Yes & Sometimes & No \\
\hline Kriva Palanka & 7 & & 6 \\
Skopje & 10 & 4 & 5 \\
Prilep & 32 & 2 & 3 \\
Krushevo & 10 & & 4 \\
Makedonski Brod & 20 & & \\
Veles & 4 & 6 & 18 \\
Total & 83 & $(5.6 \%)$ & $(16.8 \%)$ \\
\hline
\end{tabular}


$77,68 \%$ of the care providers answered positively to this question, 5,6\% of them say that the foster children sometimes play with other children, while $16,8 \%$ of them said that their foster children never play with other children. This last group includes children that cannot play with other children due to their severe disabilities, such as intellectual disabilities or combined disabilities, where the motor disabilities are dominating. This is shown in Chart 6.

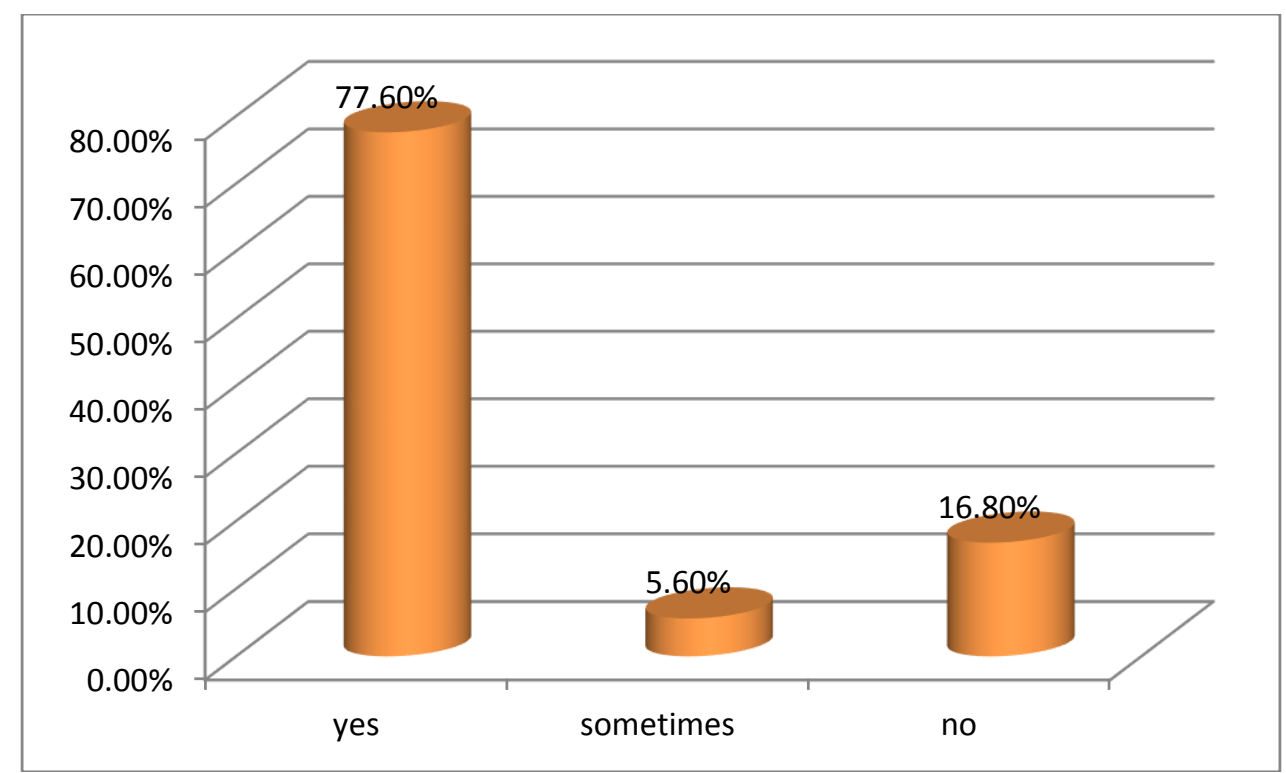

Chart 6. Does the child play with other children?

Most of the children with disabilities who are placed with foster families undertake some kind of treatments, either in the daycare centers or some other educational program. A very high percentage or $43,0 \%$ of the children are not included in any kind of professional treatment. This is usually the case with children placed in rural areas or children that cannot leave the foster family home due to their severe disabilities. 30,8\% of the children undergo treatments in the daycare centers that treat disabled children. Both care providers and social workers, and the employees in these centers point out that there is a great need to hire more defectologists in order to treat the children more effectively and with bigger quality. $16,8 \%$ of the children are included in the educational process by going to special elementary schools.

Table 7

What kind of treatment does the child undergo?

\begin{tabular}{|c|c|c|c|c|c|c|}
\hline Town/City & $\begin{array}{l}\text { not } \\
\text { included }\end{array}$ & $\begin{array}{l}\text { daycare } \\
\text { center }\end{array}$ & $\begin{array}{l}\text { special } \\
\text { elementary } \\
\text { school }\end{array}$ & $\begin{array}{l}\text { special class } \\
\text { in a regular } \\
\text { school }\end{array}$ & $\begin{array}{l}\text { regular } \\
\text { school }\end{array}$ & $\begin{array}{l}\text { special } \\
\text { high } \\
\text { school } \\
\end{array}$ \\
\hline Kriva Palanka & & 6 & 1 & & & \\
\hline Skopje & 2 & & 12 & 2 & 1 & 3 \\
\hline Prilep & 26 & 9 & 1 & 3 & & \\
\hline Krushevo & 2 & 10 & 1 & & & \\
\hline $\begin{array}{l}\text { Makedonski } \\
\text { Brod }\end{array}$ & 15 & 8 & 1 & & & \\
\hline Veles & 1 & & 2 & & & 1 \\
\hline Total & $\begin{array}{l}46 \\
(43,0 \%) \\
\end{array}$ & $\begin{array}{l}33 \\
(30,8 \%) \\
\end{array}$ & $\begin{array}{l}18 \\
(16,8 \%)\end{array}$ & $\begin{array}{l}5 \\
(4,7 \%) \\
\end{array}$ & $\begin{array}{l}1 \\
(0,9 \%)\end{array}$ & $\begin{array}{l}4 \\
(3,7 \%)\end{array}$ \\
\hline
\end{tabular}

The children who depend on the extent of their disability are included in the Rehabilitation Center of children and youth with visual impairments "Dimitar Vlahov" in Skopje, Rehabilitation Center of children and youth with hearing impairments "Kocho Racin" in Bitola and Rehabilitation Center of children and youth "Topansko Pole" in Skopje, are placed in the group of children who are included with some kind of treatment in special elementary schools. 
The group includes one child with impaired vision, attending school at the Rehabilitation Center of children and youth with visual impairments "Dimitar Vlahov" in Skopje, two children included in the Rehabilitation Center of children and youth with hearing impairments "Kocho Racin" from Bitola, and a larger group of children with intellectual disabilities that attend professional defectology treatments in the Rehabilitation Center of children and youth "Topansko Pole" in Skopje. 4,7\% of the children attend school in special classes in regular schools throughout the republic. One child is included in a regular elementary school through the process of inclusion, while 3,7\% are included in the work qualification in special high school like "Naum Ohridski" in Skopje and "Iskra" in Shtip.

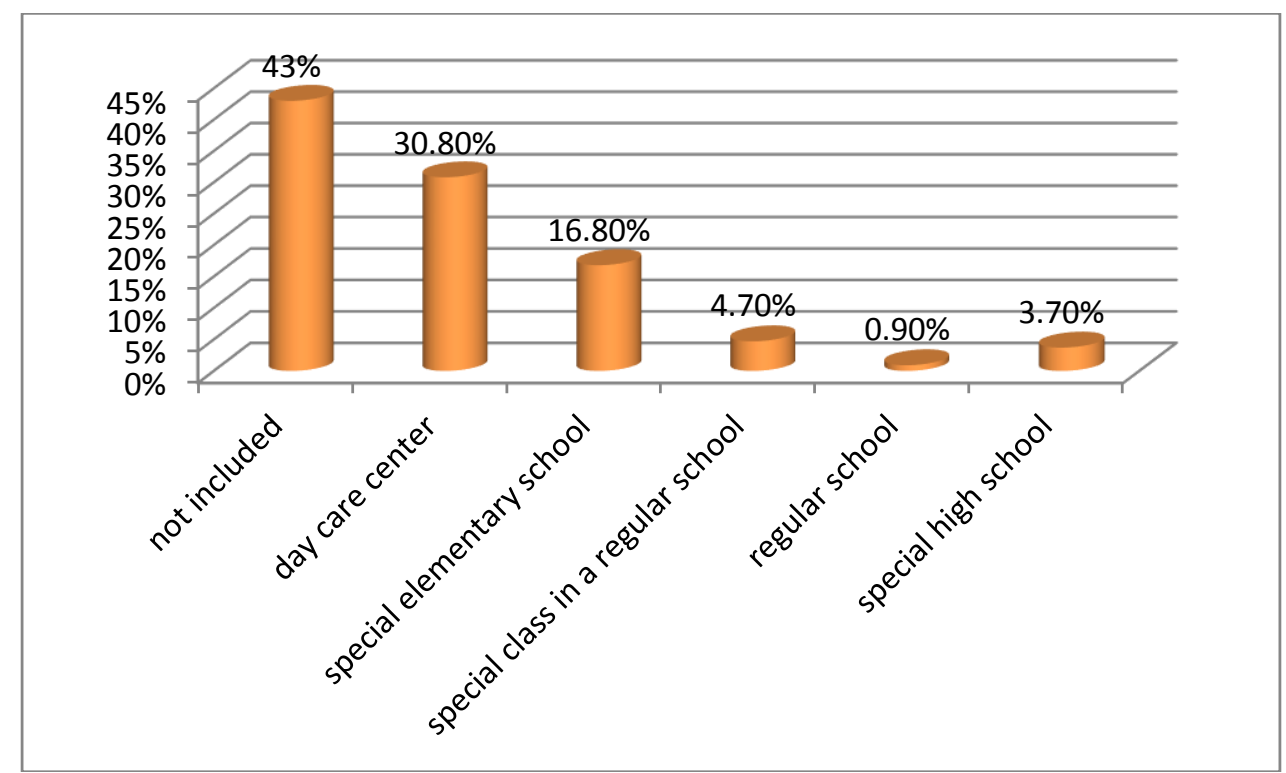

Chart 7. Types of treatment child undergo

\section{Conclusion}

Most children who are placed in foster families are children with special needs. This is mostly a result of the promotion of family care in the process of deinstitutionalization of children with special needs, who often, for various reasons, cannot return to their biological families. As a result of that, the protection of children with special needs, placed in foster families, turns into a long-term accommodation. Children with special needs can be put in "ordinary" foster families when there are no alternatives, however, there is a wide range of specialized services and programs that could respond better to their needs for care.

Problems that care providers encounter, that refer to children with disabilities / special educational needs:

a) Common health problems are often associated with children with special needs. Health problems that require additional time for their treatment and the carer must adapt to the new situation and his role in the home to be complement by another person from another family. Similar situations existed in the implementation of this research, where two carers were hospitalized with the children. Health problem carries with it a need for additional financial resources, as is the case with all other children who have some sort of disability as a condition, but no additional health problems, however, the disability requires some additional aids or special diet.

b) Carers often face the problem of the education plan. Low educational status often does not allow them to engage in the educational process of the children, or the specifics that have children with a certain type of damage do not have enough knowledge of.

c) In order to overcome these problems carers believe they need more professional help from social work centers, as well as health workers and school. During the few months of field research, we got the impression that most social workers work together with the directors of the centers for social work hard to overcome such situations. When it comes to the difficulties in terms of education, those children who are covered by the treatment can say that the special teachers include their maximum and do their best to overcome or mitigate problems. Also, special educators help in overcoming the problems of an emotional nature, especially in the period of adaptation or as was the case during the preparation for a return to the biological family. Children 
are in contact with the biological family and go for a short stay in the biological family, and after returning to the carers or to the treatment in the daily center they are under constant observation. During the observation, the special teacher monitors the health status of the children, their behavior, and the expression of their emotions.

\section{Acknowledgements}

The author would like to thank the editor for their valuable time and advice. 


\section{References}

Briones, M. F. B., Intriago, H. A. M., \& Ruiz, M. S. L. (2018). Motor Disability and Resilience in University Students. International Research Journal of Management, IT and Social Sciences (IRJMIS), 5(2), 47-54.

Cedeño, M. L. G., Rosado, I. S. M., \& Loor, K. G. R. (2018). Characterization of the Visual Disability and Its Relation with the Resilience. International Research Journal of Management, IT and Social Sciences (IRJMIS), $5(2), 32-40$.

Delgado, G. R. E., Meza, A. K. T., \& García, A. E. G. (2018). Resilient Factors in Students with Disabilities. International Research Journal of Management, IT and Social Sciences (IRJMIS), 5(2), 23-31.

García, B. B. B., Cedeño, H. A. C., Chica, T. K. M., \& Ríos, Y. R. P. (2018). Characterization of Auditory Disability and Its Relation to the Resilience. International Research Journal of Management, IT and Social Sciences (IRJMIS), 5(2), 15-22.

García, B. B. B., Zambrano, R. L. B., \& Bravo, M. G. P. (2018). Resilience in the Face of Disability. International Research Journal of Management, IT and Social Sciences (IRJMIS), 5(2), 55-63.

Macías, E. I. P., Cedeño, H. A. C., \& Chávez, G. M. R. (2018). Importance of Improving Resilience in TeachingLearning Process of Students with Disabilities. International Research Journal of Management, IT and Social Sciences (IRJMIS), 5(2), 120-128.

Macías, E. I. P., Vaca, F. A. G., \& Gavilánez, V. H. C. (2018). Resilience of Parents of Young University Students with Disabilities. International Research Journal of Management, IT and Social Sciences (IRJMIS), 5(2), 136145.

Macías, T. M. D., Barreiro, L. M. Á., \& García, D. S. V. (2018). Challenges to Foster Resilience. International Research Journal of Management, IT and Social Sciences (IRJMIS), 5(2), 80-90.

Macías, T. M. D., Meza, A. K. T., Garcia, B. B. B., \& Bozada, M. A. T. (2018). Characterization of Physical and Motor Disability at the Technical University of Manabí. International Research Journal of Management, IT and Social Sciences (IRJMIS), 5(2), 1-8.

Zambrano, R. L. B., Villamil, K. V. S., \& Cantos, K. L. G. (2018). Resilience and Personal Improvement of Students with Motor Disabilities. International Research Journal of Management, IT and Social Sciences (IRJMIS), 5(2), 96-103. 